\title{
SOLAR HEAT UTILIZATION FOR ADSORPTION COOLING DEVICE
}

\author{
Peter PILÁT ${ }^{1)}$, Marek PATSCH${ }^{2)}$ Milan MALCHO ${ }^{3)}$
}

\begin{abstract}
This article deals with possibility of solar system connection with adsorption cooling system. Waste heat from solar collectors in summer is possible to utilize in adsorption cooling systems, which desorption temperatures have to be lower than temperature of heat transport medium operation temperature. For verification of work of this system was constructed on the Department of power engineering on University of Zilina solar adsorption cooling device.
\end{abstract}

\section{INTRODUCTION}

Solar equipment is used in the summer periods only partially for hot water, whereas is the lowest heat demand for heating, while solar collectors heat profits are currently the highest at this time. Therefore rises the idea of using this excess heat for cooling, because in summer is highest consumption of energy for cooling.

\section{EXPERIMENTAL DEVICE}

Designed and constructed device is using for desorption from solar vacuum heat collector with field pipes. This is because these collectors have better performance and collectors to achieve higher operating temperatures than flat plate collectors. The collector has an effective area $3 \mathrm{~m}^{2}$. As a heat transfer medium in the collector circuits is used Alycol Thermo. The system does not work without electricity, because the collector circuit is not gravitational and works with forced circulation by using an electric pump. In the future, could the power supply not from electricity network, but from solar photovoltaic system. The proposed system is fitted with a device that needs a standard solar system (expansion tank, circulation pumps, heat exchangers, etc.). Cooling equipment is fitted with a system of tubes, pipes and valves.

\footnotetext{
1) Ing. Peter Pilát, peter.pilat@fstroj.uniza.sk

2) Ing. Marek Patsch, marek.patsch@fstroj.uniza.sk

3) prof. RNDr. Milan Malcho, Ph.D., milan.malcho@fstroj.uniza.sk

Katedra energetickej techniky, Strojnícka fakulta ŽU v Žiline

Univerzitná 8215/1, 01026 Žilina, tel.: +421 415132851
} 


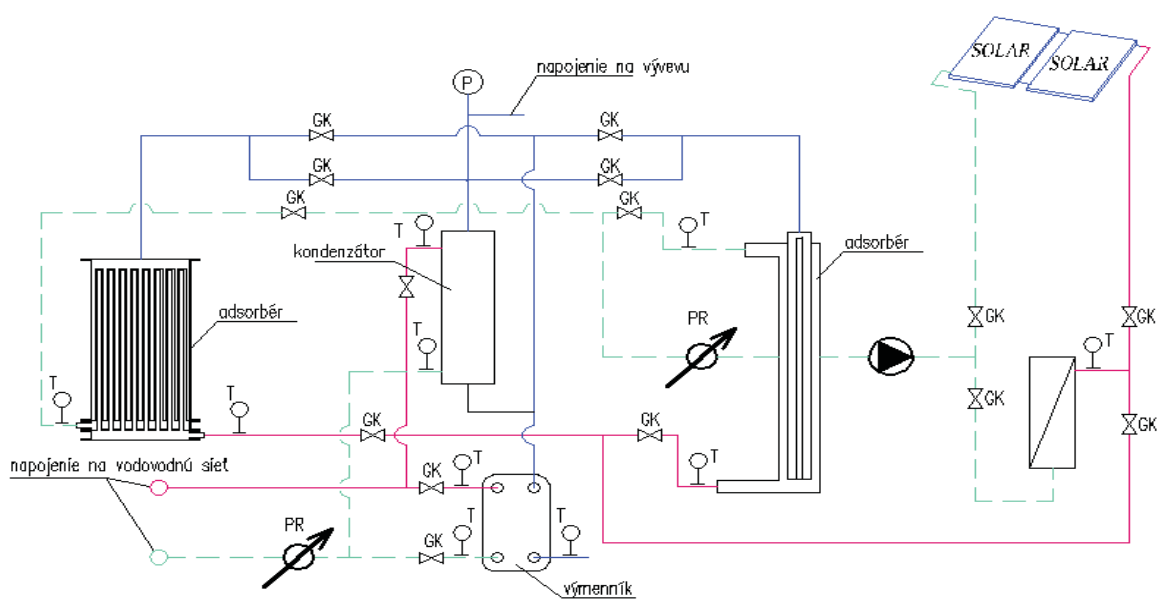

Figure 1: Scheme of experimental solar adsorption cooling system

\section{MEASURING OF SUN COLLECTOR HEAT POWER}

One of the most important parts of the system is adsorber. The adsorber is heat exchanger where is the heat exchanging between the cooling medium of the collector circuit and the adsorbent. In principle, on the correct operation of adsorption cooling device significantly affects the way of heat transport to the adsorbent. From design of adsorbers depends entire functionality of the device, because at desorption is necessary to supply desorption heat to the sorbent in the shortest time. Therefore, it must be the heat exchanger heat transfer surface on the sorbent side the largest. As the best exchanger it shows using of exchangers with ribbed surface on side of sorbent. A heat exchanger with the heat exchanger with field pipes, in which is the outer tube side ribbed for increasing of heat transfer surface.
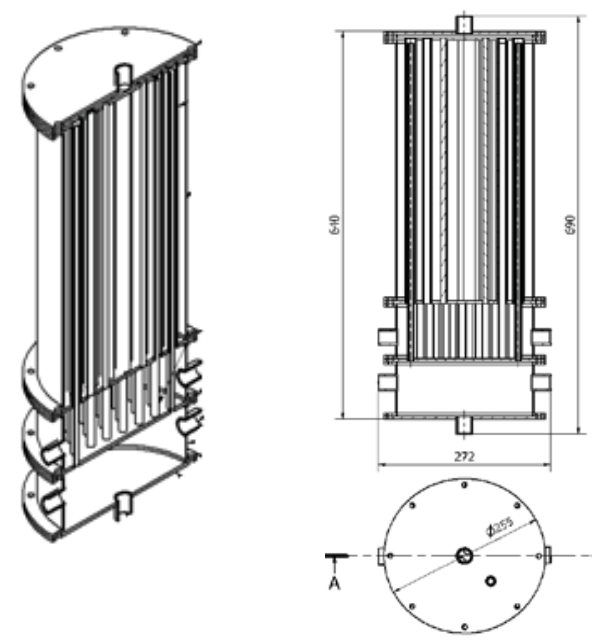

Figure 2: Adsorber/desorber with field pipes 


\section{MEASURING OF SUN COLLECTOR HEAT POWER}

The measurement of the solar collector heat power was realized on the solar device built for the purpose of providing heat for desorption of coolant in the adsorption cooling device. The solar system was built on the roof of building in the campus of University of Zilina for great work at an altitude of $380 \mathrm{~m}$ above sea. Thermal solar system performance was evaluated on base of calorimetric equation. On the experimental device was carried out several measurements. As the reference day, we have chosen the day of the first half of May at cloudy weather, the wind speed was $2 \mathrm{~ms}^{-1}$ and temperature $22^{\circ} \mathrm{C}$.

\begin{tabular}{|c|c|c|c|c|c|c|c|c|c|c|c|c|}
\hline Time & $14: 00$ & $14: 10$ & $14: 20$ & $14: 25$ & $14: 30$ & $14: 35$ & $14: 40$ & $14: 45$ & $14: 50$ & $14: 55$ & $15: 00$ & \\
\hline $\mathrm{T}_{1}$ & 9,8 & 9,76 & 9,73 & 9,73 & 9,52 & 9,47 & 9,44 & 9,4 & 9,4 & 9,4 & 9,4 & {$\left[{ }^{\circ} \mathrm{C}\right]$} \\
\hline$T_{2}$ & 16,32 & 15,22 & 12,49 & 14,43 & 13,25 & 12,93 & 13,28 & 13,57 & 13,63 & 13,12 & 12,95 & {$\left[{ }^{\circ} \mathrm{C}\right]$} \\
\hline$f$ & 129 & 129 & 129 & 129 & 129 & 128 & 129 & 129 & 129 & 129 & 129 & {$[\mathrm{~Hz}]$} \\
\hline$Q_{v}$ & 3,75 & 3,75 & 3,75 & 3,75 & 3,75 & 3,75 & 3,75 & 3,75 & 3,75 & 3,75 & 3,75 & [I.min ${ }_{1}^{-}$ \\
\hline$Q_{v}$ & $625.10^{-7}$ & $625.10^{-7}$ & $625.10^{-7}$ & $625.10^{-7}$ & $625.10^{-7}$ & $625.10^{-7}$ & $625.10^{-7}$ & $625.10^{-7}$ & $625.10^{-7}$ & $625.10^{-7}$ & $625.10^{-7}$ & {$\left[\mathrm{~m}^{3} \cdot \mathrm{s}^{-1}\right]$} \\
\hline Q & 1709 & 1431 & 724 & 1232 & 978 & 900 & 1007 & 1093 & 1109 & 975 & 931 & [W] \\
\hline
\end{tabular}

Table 1: Measured values

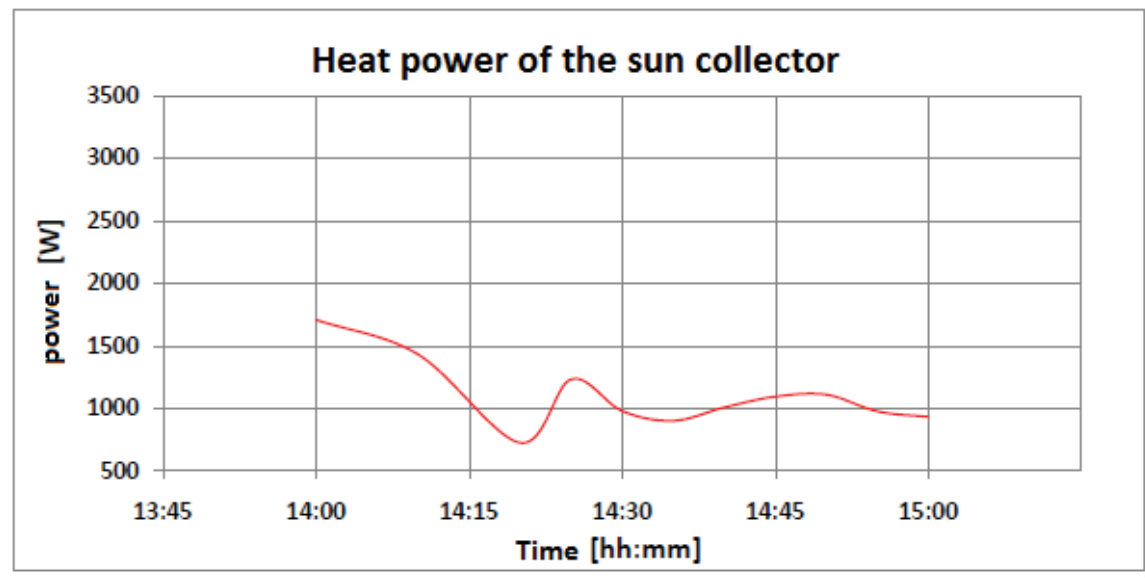

Figure 3: Graph of running of sun collector heat power

Achieved maximum power was $1709 \mathrm{~W}$, average power $1099 \mathrm{~W}$. The most important parameter for operation of the adsorption cooling device is temperature required for expulsion of refrigerant from the adsorbent, and it was maintained above the desorption temperature by throttling of the heat transfer medium flow on approximately $110^{\circ} \mathrm{C}$. 


\section{MEASURING OF ADSORPTION COOLING DEVICE COOLING POWER WITH WORKING PAIR ADSORBENT/COOLANT ACTIVE COAL/METHANOL}

Measuring of adsorption cooling device cooling power with pair adsorbent/coolant active coal/ methanol was realised 15.6.2011 from 14:02 to 17:06, when the device stopped the work. Adsorber was filled with granular activated carbon with weight $4.5 \mathrm{~kg}$. To $14.02 \mathrm{pm}$ was device tuned and the cooling power was measured from this time. The sharp increase of power was caused by vacuum pumping before start of device operation. It caused rapid boiling of coolant. After fall of power was used vacuum pump once more, what caused decreasing and then again increasing of cooling power. The average value of measured cooling power of cooling device between 14:02 and 17:06 was 134W, maximum power was reached about 14:11, and its value was $957.1 \mathrm{~W}$.

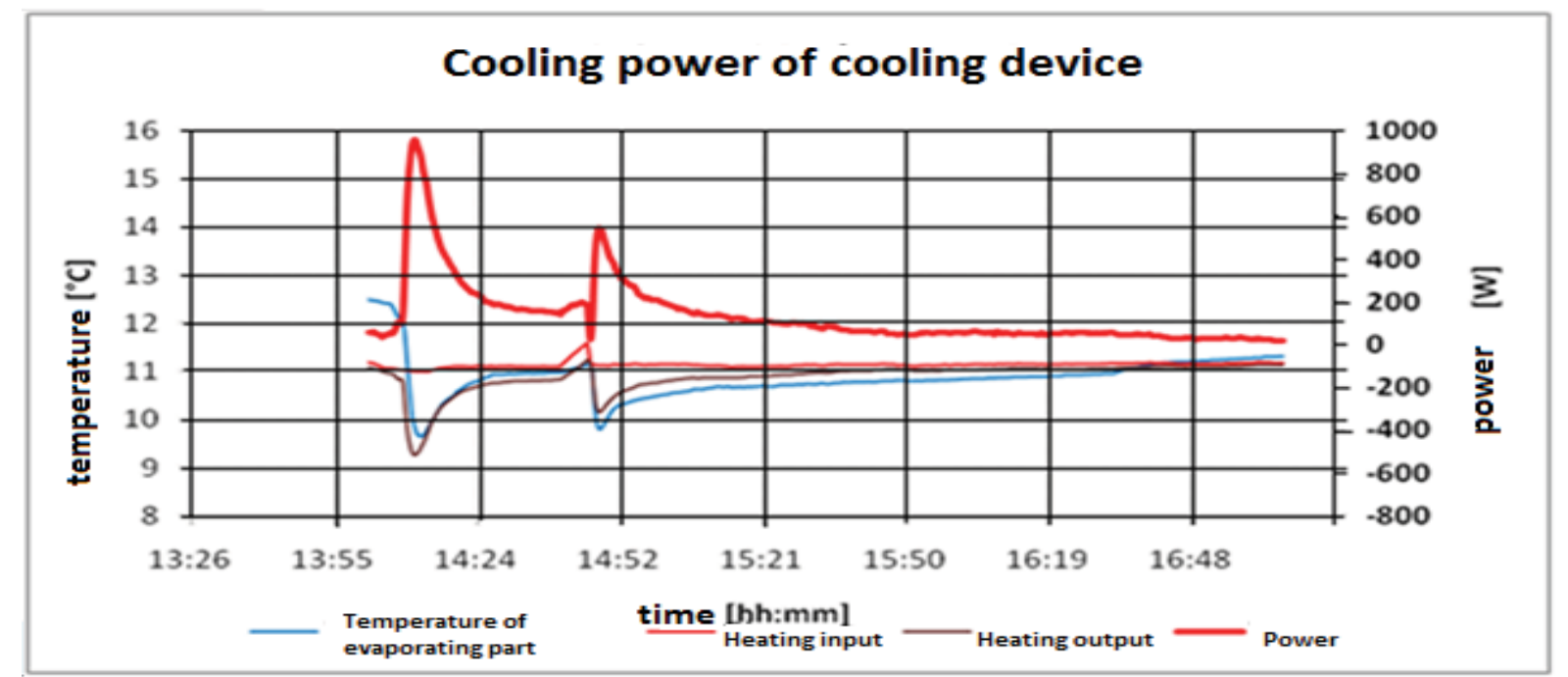

Figure 4: Graph of running of cooling power of adsorption cooling device with pair active coal/ methanol

\section{CONCLUSION}

From the measured values is obvious that the adsorption cooling system can works without problems in conjunction with a solar system. Working temperature and performance of the collector are sufficient for desorption of refrigerant from the adsorber cartridge of activated carbon already proposed in the spring months.

\section{References}

[1] Lábaj, Kapjor, Papučík, Z.: Alternatívne palivá pre energetiku a dopravu, Žilina, Georg, 2010

[2] Kaduchová K., Lenhard R., Papučík Š., Jandačka J.: Modelling of heat transfer indirectly heat water heater, ERIN 2011, 13th-16th April 2011 - Tatranská Kotlina - Vysoké Tatry - Slovakia, Prešov: Harmony Apeiron, 2011, 45-52

[3] Kaduchová K., Lenhard R., Papučík Š., Jandačka J.: Experimental measurement of indirect heat water heater, IN-TECH 2011, Bratislava, Slovakia. - [S.I.]: Jan Kudláček, 2011, 266-268. 